\title{
Effect of Root or Foliar Application of Soluble Silicon on Plant Growth, Fruit Quality and Anthracnose Development of Capsicum
}

\author{
H.A.R.K. Jayawardana*, H.L.D. Weerahewa and M.D.J.S. Saparamadu ${ }^{1}$ \\ Department of Botany, Faculty of Natural science \\ Open University of Sri Lanka \\ Sri Lanka.
}

\begin{abstract}
This study was conducted to investigate the root and foliar application of soluble silicon on plant growth, fruit quality parameters and anthracnose disease development in fruits of Capsicum annuum L. 'Muria F1'. Silicon as potassium silicate (75 $m g / l)$ was provided to root by amending the nutrient solution (T Root) at weekly interval or to foliage by spraying (T Foliar) daily, as two separate treatments. Control plants were not treated with Si. Disease resistance in fruits was assessed by artificial inoculation of Colletotrichum gloeosporioides. Plant growth and fruit quailty parameters were not significantly affected by Si treatments except firmness and cuticle thickness of fruits which were significantly greater in both $T$ Root and $T$ Foliar treated fruits than the control. This increase in fruit firmness and cuticle thickness possibly may be attributed to mechanical strength occurred by Si treatment. Sensory evaluation was carried out by a trained panel and there was no significant difference in sensory properties among the Si treated and control fruits. The fruits harvested from $T$ Root or $T$ Foliar treated plants developed significantly smaller lesions (67\% and 39\% respectively) as compared to the control. Further, the disease incidence was delayed by 2 days in both root and foliar treatments compared to the control. However, the effect of Si root treatment was significantly higher than the foliar spray against the disease.
\end{abstract}

Keywords: Anthracnose, Capsicum annuum L., Colletotrichum gloeosporioides, silicon

\section{INTRODUCTION}

Capsicum (Capsicum annuum L.) is one of the important spice/vegetable crops. Anthracnose disease caused by fungi Colletotrichum species is one of the major diseases in capsicum (Capsicum annuum L.) in tropical and sub tropical climates causing postharvest losses (Oanh et al., 2004). The disease is controlled by seed treatment and foliar spray with fungicides. However, longer use of fungicides leads to environmental and health hazards and development of fungicide resistance pathogen populations. Therefore, alternative environmental friendly control methods are needed to be investigated. The potential of soluble silicon in enhancing plant disease resistance has proven to be effective particularly, in hydroponic systems where Si availability is limited for plants (Epstein, 1994). Mainly two different application methods have been practiced to supply Si for plants; root application and foliage application. Root supplement of $\mathrm{Si}$ has been reported to cause significant reductions of powdery mildew (Adatia and Bestford, 1986) and Pythium root rot (Cherif and

1 Department of Chemistry, Faculty of Natural science, Open University of Sri Lanka, Nawala, Nugegoda, Sri Lanka

Corresponding author: ruwanikal@hotmail.com 
Belanger, 1992) of cucumber and Phytophthora blight disease of bell pepper (French-Monar et al., 2010). In a recent study, application of soluble $\mathrm{Si}$, either $100 \mathrm{mg} / \mathrm{l}$ or $75 \mathrm{mg} / \mathrm{l}$ showed highest resistance against the anthracnose disease of Capsicum 'Awlegama' (Jayawardana et al., 2014).

On the other hand, foliar application of soluble Si has been reported to reduce powdery mildew of cucumber, mask melon, zucchini squash (Menzies et al., 1992) and grapes (Bowen et al., 1992) and angular leaf spot of beans (Rodrigues et al., 2010). However, foliar spraying of $\mathrm{Si}$, if effective, may offer practical and viable mean of reducing plant diseases with low cost.

In addition to development of disease resistance, plant growth and yield have also been improved by silicon application in plants such as, cucumber (Adatia and Bestford, 1986), rice (Ma et al., 1989), and broad bean (Ghasemi et al., 2013). The objective of this study was to investigate the effect of silicon application method, either as a foliar spray or as an amendment of nutrient solution, on plant growth, fruit quality parameters and anthracnose disease development of capsicum.

\section{MATERIALS AND METHODS}

\section{Plant material}

Seeds of capsicum 'Muria F1' (East-West seed International Ltd. of Thailand) were sown on coir dust and compost medium (1:1) and were maintained in the nursery for six weeks. Healthy seedlings were transferred to non circulating liquid hydroponic system in a mesh house at $28-30{ }^{\circ} \mathrm{C}$ temperature and $80-85 \%$ relative humidity.

\section{Treatments and experimental design}

Three treatments, including the control were applied. Silicon $(75 \mathrm{mg} / \mathrm{l})$ was supplied in the form of potassium silicate which was added into the nutrient solution of the hydroponic system (T Root) or was sprayed on plant foliage (T Foliar) separately. Administration of silicon to the nutrient solution was practiced once a week while foliar spraying was practiced daily to fully wet the foliage. The plants of control treatment were not supplied with Si either through root or foliage. Treatments were arranged in Complete Randomized Design (CRD) with three replicates each with four plants. The experiment was repeated and the data were analyzed using one way ANOVA in SPSS 16 statistical package.

\section{Potassium silicate and nutrient solution}

Potassium silicate and the nutrient solution were prepared with commercial grade chemicals. Potassium silicate was prepared according to Brauer (1965) and was analyzed for molybdo reactive silica concentration using colorimetry (Clesceri et al., 1998). Two different nutrient formulations were used in growing stage (NFG) and blooming stage (NFB). The composition of NFG (mg/l) was N- 313, P- 80, K- 202, Ca- 300, Mg- 78, and the composition of NFB was N-366, P- 80, K- 650, Ca- 169, Mg- 78 and both formulas included Cu- 0.01, Fe- 3.90, Zn- 0.13, Mn- 1.20, B- 1.00 and Mo- 0.13 (Saparamadu, 2008). Proper adjustments were made in the composition of nutrient formulas to compensate the additional input of $\mathrm{K}$ when Potassium silicate was added (T Root). The $\mathrm{pH}$ of the nutrient solutions was adjusted to 6.3 using $1 \mathrm{M} \mathrm{HNO}_{3}$. Nutrient solution was renewed at weekly interval. 


\section{Pathogen isolation and identification}

Capsicum fruits with anthracnose lesions caused by Colletotrichum gloeosporioides were collected, surface sterilized with $1 \% \mathrm{NaOCl}$ for 1 minute followed by washing with sterile distilled water, cultured on PDA (Potato Dextrose Agar) media and incubated at $27-30^{\circ} \mathrm{C}$. C. gloeosporioides was isolated by sub culturing and identified by typical ovoid shape of conidia (Du et al., 2005). Fruits harvested at the colour break stage were used for the following experiments.

\section{Fruit inoculation and disease assessment}

A suspension of conidia $\left(10^{5}\right.$ conidia per $\left.\mathrm{ml}\right)$ of $C$. gloeosporioides was prepared by using 7 days old pure cultures. Three sets, each containing 10 fruits from each treatment were artificially inoculated. Each fruit was inoculated by placing drops of $(20 \mu \mathrm{l})$ conidia suspension at three different places on the surface of freshly harvested fruits. Inoculated fruits were maintained in moist chambers $\left(95-100 \%\right.$ relative humidity) at $28 \pm 2{ }^{\circ} \mathrm{C}$. The lesion area was recorded daily for 10 days. The average lesion area was calculated for each fruit.

\section{Plant growth and fruit parameters}

The shoot length, root length, internodes diameter $\left(3^{\text {rd }}-4^{\text {th }}\right.$ nodes from base), number of leaves, average leaf area and number of fruits per plant were recorded at 12 weeks after transplanting. Fruit length and fruit fresh weight of each harvested fruit were measured. Fruit width and fruit pericarp thickness were measured by a vernier caliper. Diameter at the maximum width was taken as the fruit width. Fruits were cross sectioned at the maximum width and three measurements of pericarp thickness were taken per cross section. Cross sections of fruits were mounted on a slide and cuticle thickness was measured with a calibrated ocular micrometer at 400X. Fruit dry weight was measured after being placed in a dry oven $\left(80^{\circ} \mathrm{C}\right.$ for $72 \mathrm{hrs}$ ). Fruit firmness was measured by penetrometer (Model FT 40, Wagner Instruments, Greenwich CT). Fruit extracts were prepared by crushing the fruits separately using a blender and squeezing the pulp through a muslin cloth. Total soluble solids (TSS) of fruit extracts were measured by a refractometer (Model WZ-113, China) within the range of $0-32 \%$. Brix and $\mathrm{pH}$ of the extracts was measured using $\mathrm{pH}$ meter (Model IQ150, USA). Aliquots $(5 \mathrm{ml})$ of fruit extracts were titrated against $0.1 \mathrm{M} \mathrm{NaOH}$ in the presence of phenolphthalein as an indicator and titratable acidity (\%TA) for each sample was determined according to Askar and Trepow (1993). A sensory evaluation was carried out by a trained panel to test sensory properties of harvested fruits; colour, hardness, smell, pungency and overall appearance using hedonic scale.

\section{RESULTS AND DISCUSSION}

\section{Lesion area of capsicum fruits inoculated with $C$. gloeosporioides}

The average lesion areas recorded after 10 days of pathogen $C$. goleosporioides inoculation were $54.5 \mathrm{~mm}^{2}, 99.2 \mathrm{~mm}^{2}$ and $163.6 \mathrm{~mm}^{2}$ in fruits of $\mathrm{T}$ Root, $\mathrm{T}$ Foliar and control treatments, respectively (Figure 1). The fruits obtained from T Root treated plants showed the highest disease (lesion area) reduction (67\%) compared to the control. However, the 
disease reduction observed in fruits obtained from foliage treated plants was 39\% compared to control. This was significantly lower compared to that of root treated plants.

There was a delay in symptom development observed (6 days after inoculation) in Si treated fruits (T Root or T Foliar) compared to control fruits (4 days after inoculation) (Figure 2). In addition, the fruits from control plants showed the highest rate of lesion development while the lowest rate of lesion development was recorded in fruits obtained from $\mathrm{T}$ Root treatment (Figure 2). Similarly, the anthracnose disease severity was reduced by Si root supplement in beans with a delay in disease initiation (Polanco et al., 2012). Further, the anthracnose disease of common bean has been reduced by $41 \%$ by foliar application of potassium silicate together with sodium molybdate (Polanco et al., 2014).

However, it was reported that foliar application of $\mathrm{Si}$ was less effective in controlling the powdery mildew of wheat than the root application (Guevel et al., 2007).

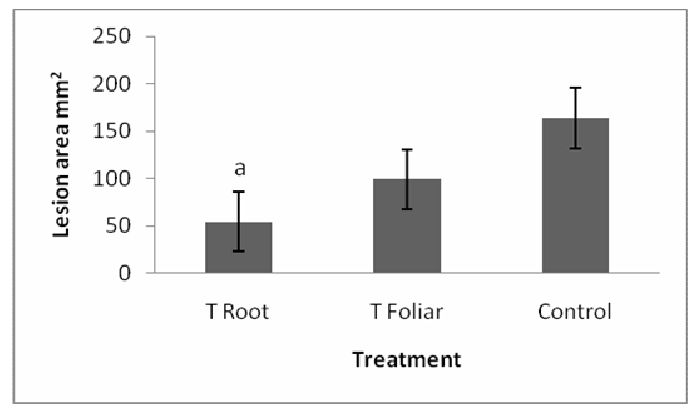

Fig. 1. Lesion area $\left(\mathrm{mm}^{2}\right)$ of capsicum fruits at 10 days after inoculation of Colletotrichum gloeosporioides. Bars with the same letter are not significantly different $(\mathrm{P} \leq 0.05)$ as determined by Tuckey HSD test.

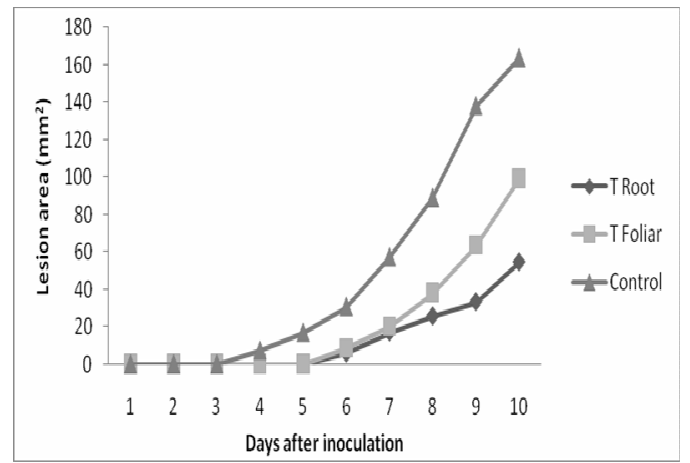

Fig. 2. Lesion development of capsicum fruits inoculated with Colletotrichum gloeosporioides.

It is also reported that application of potassium silicate to soil at $1.7 \mathrm{mM}(100 \mathrm{mg} / \mathrm{l}) \mathrm{did}$ not reduce the number of powdery mildew colonies on grape leaves, while foliar sprays of potassium silicate at $17 \mathrm{mM}$ concentration reduced the number of powdery mildew colonies by over $60 \%$ (Bowen et al., 1992). However, $17 \mathrm{mM}$ concentration far exceeds the standard $1.7 \mathrm{mM}$ in root application (Guevel et al., 2007). It has been reported that there was no difference of $\mathrm{Si}$ concentration in bean leaf tissues when the plants subjected to Si spray compared to that of control plants (Rodrigues et al., 2010). Also, wheat plants treated with 
root application of Si had higher level of Si deposition in comparison with foliar application which accumulated very little $\mathrm{Si}$. The above findings suggest that amount of soluble $\mathrm{Si}$ absorbed through foliage is lesser than root.

The mechanism underlying with disease resistance caused by $\mathrm{Si}$ in plants has been explained in different ways, i.e. Si acts as a physical barrier and induces biochemical defence responses similar to systemic acquired resistance in plants (Cai et al., 2009). The mechanism underlying the disease reduction by foliar Si treatments possibly could be the physical barrier formed due to coating of crystals on the leaf surface by the spray (Guevel et al., 2007). Liang et al. (2005) suggested that foliar application of Si gave a satisfactory disease control probably through a physical barrier caused by deposited Si on leaf surfaces or an osmotic effect of the silicates, but was not able to enhance the enzymes involved in host defence responses. On the other hand, continuous root application of $\mathrm{Si}$ induced systemic acquired resistance. It could be suggested that $\mathrm{Si}$ applied on both root and foliage has ability to delay the disease initiation while, Si supplied through root has a further inhibitory action on fungal development that showed lowest growth of lesion area with time.

\section{Plant growth and fruit parameters}

There was no significant effect on growth parameters in crops treated with Si compared to the control (Table 1). Among the fruit parameters, fruit firmness and cuticle thickness were significantly greater in both root and foliage treatments compared to control whereas other tested fruit parameters were not affected by Si application (Table 1).

Table 1. Effect of different Si treatments on plant growth and fruit parameters

\begin{tabular}{llccc}
\hline Plant growth and fruit parameters & T Root & T Foliar & Control \\
\hline Plant growth & Shoot length $(\mathrm{cm})$ & $62^{\mathrm{a}}$ & $58^{\mathrm{a}}$ & $60^{\mathrm{a}}$ \\
parameters & Root length $(\mathrm{cm})$ & $20.3^{\mathrm{a}}$ & $19.3^{\mathrm{a}}$ & $18.7^{\mathrm{a}}$ \\
& Inter node $(3-4)$ diameter $(\mathrm{cm})$ & $3.4^{\mathrm{a}}$ & $3.4^{\mathrm{a}}$ & $3.1^{\mathrm{a}}$ \\
& No. of leaves & $65^{\mathrm{a}}$ & $60^{\mathrm{a}}$ & $58^{\mathrm{a}}$ \\
& Average leaf area $\left(\mathrm{cm}^{2}\right)$ & $40^{\mathrm{a}}$ & $45^{\mathrm{a}}$ & $45^{\mathrm{a}}$ \\
\hline Fruit & No. of fruits & $09^{\mathrm{a}}$ & $08^{\mathrm{a}}$ & $08^{\mathrm{a}}$ \\
parameters & Fruit length $(\mathrm{cm})$ & $14.6^{\mathrm{a}}$ & $13.5^{\mathrm{a}}$ & $13.3^{\mathrm{a}}$ \\
& Fruit width $(\mathrm{cm})$ & $2.75^{\mathrm{a}}$ & $2.67^{\mathrm{a}}$ & $2.65^{\mathrm{a}}$ \\
& Fruit pericarp thickness $(\mathrm{mm})$ & $4.0^{\mathrm{a}}$ & $4.1^{\mathrm{a}}$ & $3.9^{\mathrm{a}}$ \\
& Fruit fresh weight $(\mathrm{g})$ & $30^{\mathrm{a}}$ & $28^{\mathrm{a}}$ & $25^{\mathrm{a}}$ \\
& Fruit dry weight $(\%$ of fresh weight) & $5.5^{\mathrm{a}}$ & $6.0^{\mathrm{a}}$ & $5.1^{\mathrm{a}}$ \\
& Cuticle thickness $(\mu \mathrm{m})$ & $37.03^{\mathrm{b}}$ & $37.86^{\mathrm{b}}$ & $18.51^{\mathrm{a}}$ \\
& Fruit firmness $(\mathrm{N})$ & $23.53^{\mathrm{b}}$ & $25.13^{\mathrm{b}}$ & $19.6^{\mathrm{a}}$ \\
& Total soluble solids $\left({ }^{\mathrm{o}}\right.$ Brix) & $7.5^{\mathrm{a}}$ & $7.4^{\mathrm{a}}$ & $7.0^{\mathrm{a}}$ \\
& $\%$ TA & $0.54^{\mathrm{a}}$ & $0.53^{\mathrm{a}}$ & $0.54^{\mathrm{a}}$ \\
& pH & $5.53^{\mathrm{a}}$ & $5.42^{\mathrm{a}}$ & $5.70^{\mathrm{a}}$ \\
\hline
\end{tabular}

Means followed by the same letter within the same row are not significantly different $(\mathrm{P} \leq 0.05)$ as determined by Tuckey HSD test.

Similarly, fruit fresh and dry weight, TSS, titratable acidity of Cucumis melo L. were not affected by root application of Si (Butttaro et al., 2009) and plant growth of wheat was not affected by foliar or root treatments of Si (Guevel et al., 2007). However, increased fruit firmness and cuticle thickness seemed to be involved in disease reduction. The fruits of $C$. gloeosporioides resistant Capsicum baccatum 'PBC80' had thicker cuticle than that of susceptible Capsicum annuиm 'Jejujaerae' revealing that thick cuticle of pepper possibly act 
as a pre existing structural barrier to fungal penetration (Kim et al., 2004). It has been also shown that there is a negative correlation between cuticle thickness and disease incidence caused by C. gloeosporioides in pepper fruits (Oh et al., 1999).

The penetration of germinating fungal spores in grapes treated with potassium silicate foliar spray was prevented by thick potassium silicate deposits that coated a significant portion of the grape leaf cuticle (Bowen et al., 1992) as well. Therefore, there may be a possibility of involving the physical barrier formation for the disease reduction in fruits of the plants subjected to Si treatments compared to control.

There was no significant difference observed among treatments in tested sensory properties of fruits: fruit colour, fruit hardness, overall appearance, pungency and smell (Table 2). Almost all sensory properties were highly favoured by the panel slightly or moderately or extremely.

Table 2. Mean ranks obtained for the results of sensory evaluation (Hedonic scores ${ }^{\mathrm{x}}$ ) as determined by Kruskal Wallis test

\begin{tabular}{lccccc}
\hline Treatments & $\begin{array}{c}\text { Fruit } \\
\text { colour }\end{array}$ & $\begin{array}{c}\text { Fruit } \\
\text { hardness }\end{array}$ & $\begin{array}{c}\text { Overall } \\
\text { appearance }\end{array}$ & Pungency & Smell \\
\hline T Root & $18.30^{\mathrm{a}}$ & $16.30^{\mathrm{a}}$ & $19.70^{\mathrm{a}}$ & $17.10^{\mathrm{a}}$ & $16.50^{\mathrm{a}}$ \\
T Foliar & $16.20^{\mathrm{a}}$ & $11.90^{\mathrm{a}}$ & $14.30^{\mathrm{a}}$ & $16.50^{\mathrm{a}}$ & $16.50^{\mathrm{a}}$ \\
control & $12.00^{\mathrm{a}}$ & $18.30^{\mathrm{a}}$ & $12.50^{\mathrm{a}}$ & $12.90^{\mathrm{a}}$ & $13.50^{\mathrm{a}}$ \\
\hline
\end{tabular}

${ }^{\mathrm{x}}$ Hedonic scores ranged from 1-7 where $1=$ Extremely dislike and $7=$ extremely like.

${ }^{a}$ There was no significant difference among treatments in any sensory property $(\mathrm{P} \leq 0.05)$ as determined by Kruskal-Wallis test.

\section{CONCLUSIONS}

Silicon treatments had no significant effect on consumer preference, plant growth and fruit parameters except fruit firmness and cuticle thickness. However, root supplement of Si was effective over foliar spraying against anthracnose disease development caused by Colletotrichum gloeosporioides in Capsicum annuum L. 'Muria Fl'.

\section{ACKNOWLEDGMENT}

National Science Foundation and the Faculty Grant of the Faculty of Natural Science, OUSL are kindly acknowledged for funding the research.

\section{REFERENCES}

Adatia, M.H. and Bestford, R.T. (1986). The Effects of Silicon on Cucumber Plants Grown in Recirculating Nutrient Solution. Ann. Bot. 58, 343 - 351.

Askar, A. and Trepow, H. (1993). Quality Assurance in Tropical Fruit Processing. SpringerVerlay, New York. 9 - 25.

Bowen, B., Menzeies, J. and Ehert, D. (1992). Soluble silicon sprays inhibit powdery mildew development on grape leaves. J Amer. Soc. Hort. Sci. 117(6), 906 - 912. 
Brauer, G. (Ed.). (1965). Handbook of preparative inorganic chemistry vol. 1(2 $2^{\text {nd }}$ ed.). Acedemic press, Inc. (London) Ltd, London W.1.

Buttaro, D., Bonasia, A., Minuto, A., Serio, F. and Santamaria, P. (2009). Effect of silicon in the nutrient solution on the incidence of the powdery mildew and quality traits in carosello and barattiere (Cucumis melo L.) grown in a soilless system. Journal of Horticultural Science \& Biotechnology. 84, 300 - 304.

Cai, K.Z., Gao, D., Chen, J. and Luo, S. (2009). Probing the mechanism of silicon mediated pathogen resistance. Plant signaling and behavior. 4, 1 - 3 .

Cherif, M. and Belanger, R. R. (1992). Use of potassium silicate amendments in recirculating nutrient solutions to suppress Pythium ultimum on long English cucumber. Plant Disease. 79, $1008-1011$.

Clesceri, S.L., Greenburge, A.E. and Eaton, A.D. (Eds). (1998). Standard methods for the examination of water and waste water. $\left(20^{\text {th }}\right.$ ed.). American public health association. United book press, Baltimore, Maryland, USA.

Du, M. Schardl, C.L., Nuckles, E.M. and Vaillancourt, L.J. (2005). Using mating-type gene sequences for improved phylogenetic resolution of Colletotrichum species complexes. Mycologia. 97, $641-658$.

Epstein, E. (1994). The anomaly of silicon in plant biology. Proceedings of The National Academy of Sciences USA, 91, 11 - 17.

French-Monar, R.D., Rodrigues, F.A., Korndorfer, G.H. and Datnoff, L.E. (2010). Silicon suppresses Phytophthora blight development on bell pepper. Journal of Phytopathology. 58, $554-560$.

Ghasemi, A., Ejraei, A. and Rajaei, M. (2013). Effect of Silicon on vegetative and generative performance of Broad Bean (Vicia faba L.) J Nov . Appl Sci. 2(S), 881 - 884.

Guével, M.H., Menzies, J.G., and Bélanger, R.R. (2007). Effect of root and foliar applications of soluble silicon on powdery mildew control and growth of wheat plants. Eur. J. Plant Pathol. 119, 429 - 436.

Jayawardana H.A.R.K., Weerahewa H.L.D., Saparamadu M.D.J.S. and Rathnayaka R.M.A.C. (2014). Effect of Silicon on anthracnose disease in hydroponically grown Capsicum annum L. cv. Awlegama. Proceedings of the Peradeniya Univ. International Research Sessions, Sri Lanka, 18, p 543.

Kim, K.H., Yoon, J.B., Park, H.G., Park, E.W., Kim and Y.H. (2004). Structural modifications and programmed cell death of chili pepper fruits related to resistance responses to Colletotrichum gloeosporioides infection. Phytopathology. 94, 1295 - 1304.

Liang, Y.C., Sun, W.C., Si, J. and Romheld, V. (2005). Effects of foliar- and root-applied silicon on the enhancement of induced resistance to powdery mildew in Cucumis sativus. Plant Pathol. 54, 678 - 85. 
Ma, J., Nishimura, K. and Takahashi, E. (1989). Effect of silicon on the growth of rice plants at different growth stages. Soil Science and Plant Nutrition. 35, 347 - 356.

Menzies, J, Bowen, P, Ehret, D.L. and Glass A.D.M. (1992).Foliar application of potassium silicate reduce severity of powdery mildew on cucumber, muskmelon and zucchini squash. J.Am. soc. Hortic.Sci. 117, 902 - 905.

Oanh, L.T.K., Korpraditskul, V. and Rattanakreetakul, C. (2004). A pathogenicity of anthracnose fungus, Colletotrichum capsici on various Thai chili varieties. Kasetsart Journal (Natural Science). 38, 103 - 108.

Oh, B.J, Kim, K.D. and Kim, Y.S. (1999). Effect of cuticular wax layers of green and red pepper fruits on infection by Colletotrichum gloeosporioides. Journal of Phytopathology. $147,547-552$.

Polanco, L.R., Rodrigues, F.A., Nascimento, K.J.T., Shulman, P., Silva, L.C., Neves, F.W. and Vale, F.X.R. (2012). Biochemical aspects of bean resistance to anthracnose mediated by silicon. Annals of Applied Biology. 161, 140 - 150.

Polanco, L.R., Rodrigues, F.A., Moreira, E.N, Duarte, H.S.S., Cacique, I. S., Valente, L.A., Vieira, R. F., Paula Júnior, T. J. and Vale F. X. R. (2014). Management of Anthracnose in Common Bean by Foliar Sprays of Potassium Silicate, Sodium Molybdate, and Fungicide. Plant Disease. 98, 84 - 89.

Rodrigues, F.Á., Duarte, H.S.S. Rezende, D.C., Wordell Filho, J.A., Korndörfer, G.H. and Zambolim, L. (2010) Foliar spray of potassium silicate on the control of angular leaf spot on beans, Journal of Plant Nutrition. 33(4), 2082 - 2093.

Saparamadu, M.D.J.S. (2008). Development of a user friendly and cost effective nutrient management strategy for simplified hydroponics. MPhil Thesis, University of Colombo, Sri Lanka. 